\title{
PERLINDUNGAN HUKUM BAGI KONSUMEN DENGAN ADANYA KLAUSUL EKSONERASI DALAM PERJANJIAN BAKU SEWA GUNA USAHA (LEASING)
}

\author{
Alfikhi Abdul Rahman \\ Universitas Andalas, alfikbiabdulrahman@gmail.com
}

Diterima: 23 Desember $2019 \quad$ Direvisi : 07 Juli $2020 \quad$ Diterbitkan: 09 Juli 2020

\begin{abstract}
The problems examined in this paper are: How is the material content of the exoneration clause in the lease standard agreement that causes losses for consumers of PT. Dipo Star Finance branch of Padang and how the judges consider in deciding the principal case of leasing based on Decision Number 4/Pdt.G/2017/PN.Pdg. In this study, the method used is normative juridical which is descriptive where the datas are sourced from primary and secondary data obtained based on the study of documents analyzed qualitatively. From this research, it can be concluded that at the time of making the finance lease agreement there is a will of disability regarding article 29 of the lease agreement and is an exoneration clause that is very detrimental to the consumer. Lesse does not know that collateral for other agreements is a guarantee of the object of the agreement that has paid off. Based on the judgment of the judge and the statement from the witness of the agreement law, article 29 of the lease agreement binds both parties based on the principle of pacta sunt servanda, but no statement or word is found which confirms that the guarantee for the agreement that has ended is a guarantee against other agreements, so that the guarantee becomes multi-interpretation. Article provisions relating to agreement one with other agreements in the agreement is very detrimental to consumers and contrary to article 10 letter (c) of Law Number 8 of 1999 concerning Consumer Protection.
\end{abstract}

Keywords: Business Lease, Exoneration Clause, Standard Agreement.

\begin{abstract}
Abstrak
Masalah yang diteliti dalam penulisan ini yaitu: Bagaimana materi muatan klausul eksonerasi pada perjanjian baku sewa guna usaha (leasing) yang menimbulkan kerugian bagi konsumen PT Dipo Star Finance cabang Padang dan Bagaimana pertimbangan hakim dalam memutuskan pokok perkara perjanjian baku sewa guna usaha (leasing) berdasarkan Putusan Nomor 4/Pdt.G/2017/PN.Pdg. Pada penelitian ini, metode yang digunakan adalah yuridis normatif yang bersifat deskriptif dimana datanya bersumber dari data primer dan sekunder yang diperoleh berdasarkan studi dokumen yang dianalisis secara kualitatif. Dari penelitian tersebut dapat ditarik kesimpulan bahwa pada waktu lahirnya perjanjian finance lease terdapat cacat kehendak mengenai pasal 29 perjanjian lease tersebut dan merupakan klausul eksonerasi yang sangat merugikan konsumen. Lesse tidak mengetahui bahwa jaminan terhadap perjanjian yang lain merupakan jaminan terhadap objek perjanjian yang sudah lunas pembayaranya. Berdasarkan pertimbangan hakim dan keterangan saksi ahli hukum, perjanjian pasal 29 perjanjian lease mengikat kedua belah pihak berdasarkan asas pacta sunt servanda namun, tidak ditemukan pernyataan atau kata yang menegaskan bahwa jaminan terhadap perjanjian yang telah berakhir merupakan jaminan terhadap perjanjian lainnya, sehingga jaminan menjadi multitafsir. Pasal ketentuan keterkaitan perjanjian satu
\end{abstract}


dengan perjanjian lainnya dalam perjanjian tersebut sangat merugikan konsumen serta bertentangan dengan pasal 10 huruf (c) Undang-Undang Nomor 8 tahun 1999 tentang Perlindungan Konsumen.

Kata Kunci : Klausul Eksonerasi, Perjanjian Baku, Sewa Guna Usaha

\section{PENDAHULUAN}

Modal berdasarkan sumbernya dibedakan menjadi 2 (dua), yaitu modal internal dan modal eksternal. Sumber modal internal merupakan modal yang didapatkan dari perusahaan itu sendiri biasanya dari hasil penjualan. Sumber modal eksternal adalah modal yang berasal dari luar perusahaan atau dana yang diperoleh dari para kreditur ataupun dari pemegang saham yang dapat ambil bagian dalam perusahaan. Modal eksternal ini umumnya didapatkan dari koperasi, lembaga keuangan baik bank maupun non bank dan lembaga pembiayaan. ${ }^{1}$

Modal eksternal dalam prakteknya didapatkan melalui persetujuan pihak yang akan memberikan modal dan pihak yang akan menerima modal sehingga dari persetujuan tersebut lahirlah suatu perjanjian atau perikatan. Persetujuan adalah salah satu sumber perikatan selain daripada undang-undang, hal ini dapat

1 Maxmanroe.com, Pengertian Modal Secara Umum, Manfaat, Sumber, dan JenisJenis Modal, https://www.maxmanroe.com/vid/bisnis/penger tian-modal.html, Terakhir diakses tanggal 2 Desember 2018 . dilihat dalam ketentuan Pasal 1233 Kitab Undang-Undang Hukum Perdata (KUHPerdata) yang menyebutkan bahwa tiap-tiap perikatan lahir baik karena persetujuan ataupun karena undangundang.

Menurut C. Asser-A.S. Hartkamp Perjanjian adalah suatu perbuatan atau tindakan hukum yang terbentuk dengan tercapainya kata sepakat yang merupakan pernyataan kehendak bebas dari dua orang (pihak) atau lebih, dimana tercapainya sepakat tersebut tergantung dari para pihak yang menimbulkan akibat hukum untuk kepentingan pihak yang satu dan atas beban pihak yang lain atau timbal balik dengan mengindahkan ketentuan perundang-undangan. ${ }^{2}$

Gambaran mengenai perjanjian tentunya sudah melekat dalam kehidupan sehari-hari baik disadari ataupun tidak, misalnya dalam sewa guna usaha (leasing) yang sudah menjadi hal umum di kalangan para pengusaha merupakan

2 C. Asser-A.S dalam Herlien Budiono, 2009, Ajaran Umum Hukum Perjanjian dan Penerapannya di Bidang Kenotariatan, Citra Aditya Bakti, Bandung, hlm 3. 
bentuk sebuah perjanjian yang mengikat para pihak. Sewa guna usaha adalah istilah yang dipakai dalam peraturan tentang Lembaga Pembiayaan sebagai terjemahan dari istilah bahasa Inggris leasing dari kata dasar lease, artinya sewa-menyewa. Kemudian, dalam dunia bisnis berkembang leasing sebagai bentuk khusus sewa-menyewa, yaitu dalam bentuk pembiayaan perusahaan berupa penyediaan barang modal yang digunakan untuk menjalankan usahanya dengan membayar sewa selama jangka waktu tertentu. $^{3}$

Apabila menyebut leasing, maka yang dimaksud adalah sewa guna usaha, akan tetapi dalam ketentuan pasal tersebut tidak ada ketegasan apakah sewa guna usaha (leasing) tersebut dalam bentuk kontrak. Hal ini baru jelas apabila membaca ketentuan Pasal 9 Keputusan Menteri Keuangan Nomor 1169 Tahun 1991:

"Setiap transaksi Sewa Guna Usaha wajib diikat dalam suatu Perjanjian Sewa Guna Usaha (Lease Agreement). Perjanjian Sewa Guna Usaha wajib dibuat dalam bahasa Indonesia dan apabila dipandang perlu dapat diterjemahkan ke dalam bahasa asing. ${ }^{4}$

3 Abdulkadir Muhammad dan Rilda Murniati, 2000, Segi Hukum Lembaga Keuangan dan Pembiayaan. PT. Citra Aditya Bakti, Bandung, hlm 201.
Seiring dengan perkembangan di bidang ekonomi dan perdagangan yang semakin tumbuh pesat dengan diikuti transaksi bisnis yang tinggi, maka masyarakat menuntut untuk membuat perjanjian cepat, efisien dan efektif. Dari tuntutan untuk membuat perjanjian cepat, efisien dan efektif inilah kemudian timbul istilah perjanjian atau kontrak baku atau kontrak standar (standard contract) yaitu suatu kontrak tertulis yang dibuat oleh salah satu pihak, bahkan sering kali kontrak tersebut sudah tercetak dalam bentuk formulir-formulir tertentu oleh salah satu pihak yang dalam hal ini ketika kontrak tersebut ditandatangani umumnya para pihak hanya mengisikan data-data informatif tertentu saja dengan sedikit atau bahkan tanpa perubahan dalam klausulklausulnya, dimana pihak lain dalam kontrak tersebut tidak mempunyai kesempatan atau sedikit kesempatan untuk negosiasi atau mengubah klausulklausul yang sudah dibuat oleh salah satu pihak tersebut. $^{5}$

Dalam suatu perjanjian tercantum klausul-klausul tertentu yang dilakukan oleh pihak-pihak yang memiliki

${ }^{4}$ Amin Widjaya Tunggal \& Arif Djohan Tunggal dalam Abdulkadir Muhammad dan Rilda Murniati, Op. Cit, hlm 203.

${ }^{5}$ Munir Fuady, 2003, Hukum Kontrak (Dari Sudut Pandang Hukum Bisnis), Buku Kedua, Citra Aditya Bakti, Bandung, hlm 76. 
kedudukan yang lebih kuat yang mengakibatkan sangat merugikan pihak yang lemah yang dapat menimbulkan penyalahgunaan keadaan. $^{6}$ Klausulklausul yang merugikan pihak debitur ini disebut dengan klausul eksonerasi yang mana bertentangan dengan UndangUndang Nomor 8 Tahun 1999 tentang Perlindungan Konsumen. Eksonerasi (exoneration) adalah membebaskan seseorang atau badan usaha dari suatu tuntutan atau tanggung jawab hukum. ${ }^{7}$

Bentuk perjanjian baku leasing dengan hak opsi (finance lease) yang dilakukan antara Alexander sebagai lessee dengan PT. Dipo Star Finance cabang Padang sebagai lessor, Nomor: 0008162/1/09/10/2011 tertanggal 06 Oktober 2011 tentang objek pembiayaan barang modal berupa 1 unit Mitsubishi Pajero Sport GLS M/T 4x2 2011, dengan jangka waktu 36 bulan yang mana harga telah disepakati hingga lunas. Kemudian pada tanggal 08 Desember 2011 antara Alexander dengan PT. Dipo Star Finance Cabang Padang kembali mengadakan perjanjian leasing dengan hak opsi (finance lease), Nomor: 0008592/1/09/12/2011 tentang objek pembiayaan barang modal berupa 1 unit Mitsubishi Fuso Truck E2

${ }^{6}$ Ahmadi Miru dan Sutarman Yodo, 2008, Hukum Perlindungan Konsumen, Jakarta, PT RajaGrafindo Persada, hlm 115.
FN527ML 2011/1 unit Karoseri Dump Truck 2011, dengan jangka waktu 48 bulan yang mana harga telah disepakati bersama.

Pada tanggal 10 November 2014 lessee telah membayar lunas harga objek pembiayaan barang modal pada Perjanjian Leasing Nomor : 0008162/1/09/10/2011 beserta denda keterlambatannya dan lessee sesuai isi perjanjian dengan itu menggunakan hak opsinya untuk membeli objek barang tersebut berdasarkan Deposito Jaminan yang kemudian dikompensasikan dengan Nilai Sisa Barang yang telah disepakati bersama sehingga lessee demi hukum menjadi pemilik dari objek tersebut. Pada saat lessee meminta penyerahan Bukti Pemilikan Kendaraan Bermotor (BPKB) yang menjadi dasar suatu nilai atas kendaraan tersebut, lessor tidak bersedia memberikannya kepada lessee dengan alasan lessee mempunyai hutang kredit lainnya yang masih berjalan yaitu Perjanjian Leasing Nomor: 0008592/1/09/12/2011.

Pada Perjanjian Leasing pertama maupun Perjanjian Leasing kedua, pihak lessor memberlakukan syarat Ketentuan Keterkaitan yang dimuat di dalam Pasal

${ }^{7}$ Mariam Darus Badrulzaman, 2008, Aneka Hukum Bisnis, Alumni, Bandung, hlm 47. 
29 masing-masing perjanjian leasing tersebut yang berbunyi sebagai berikut: "Pasal 29 : Keterkaitan

(1) Dalam hal Lessee disamping memperoleh fasilitas lease berdasarkan Perjanjian ini, juga memperoleh fasilitas pembiayaan dari Lessor, baik dalam bentuk fasilitas leasing atau fasilitas pembiayaan lainnya, maka kelalaian atas salah satu perjanjian pembiayaan itu akan merupakan kelalaian atas Perjanjian ini, juga kelalaian atas Perjanjian ini akan merupakan kelalaian atas Perjanjian atau perjanjian-perjanjian pembiayaan lainnya itu.

(2) Pada Kelalaian menurut ayat lalu, maka hak-hak yang dimiliki oleh Lessee dalam Perjanjian ini akan merupakan jaminan terhadap kewajibankewajibannya dalam perjanjian pembiayaan yang lainnya itu dan sebaliknya hak-hak dalam perjanjian pembiayaan lainnya dengan sendirinya menjadi jaminan terhadap kewajiban Lease menurut Perjanjian ini.

Dalam hal ini jaminan yang dimaksudkan

dalam Pasal 29 perjanjian tersebut telah menyesatkan debitur sehingga pelunasan dan opsi membeli debitur dianggap tidak ada artinya.

Mengenai permasalahan hukum yang timbul dari perjanjian baku leasing tersebut pihak debitur telah melakukan upaya hukum diluar peradilan demi mendapatkan keadilan seperti mengadukan kreditur ke Badan Penyelesaian Sengketa Konsumen (BPSK), namun putusan BPSK tersebut dibatalkan oleh Pengadilan Negeri Padang pada tanggal 26 Februari 2015 karena kreditur mengajukan keberatan atas putusan BPSK tersebut. Kemudian debitur kembali melakukan upaya hukum dengan menggugat kreditur melalui Pengadilan Negeri Padang dan pada tanggal 27 Juni 2017 Pengadilan Negeri Padang membacakan Putusan atas Perkara Perdata dalam persidangan terbuka untuk umum dengan Putusan Nomor 4/Pdt.G/2017/PN.Pdg antara lessee sebagai Penggugat dengan lessor sebagai Tergugat. Namun pada Putusan tersebut Pengadilan Negeri Padang menolak gugatan penggugat seluruhnya karena tindakan dari lessor yang belum menyerahkan BPKB milik lessee adalah bukan merupakan perbuatan melawan hukum melainkan hal tersebut telah disepakati bersama antara lessee dan lessor berdasarkan Pasal 29 dalam Perjanjian Leasing tersebut.

Berdasarkan latar belakang permasalahan yang telah diuraikan sebelumnya, dapat dirumuskan pokok permasalahan sebagai berikut:

1. Bagaimana materi muatan klausula eksonerasi pada perjanjian baku sewa guna usaha (leasing) yang menimbulkan kerugian bagi konsumen PT Dipo Star Finance cabang Padang?

2. Bagaimana pertimbangan hakim dalam memutuskan pokok perkara 
perjanjian baku sewa guna usaha (leasing) berdasarkan Putusan Nomor 4/Pdt.G/2017/PN.Pdg?

\section{METODE PENELITIAN}

Demi memperoleh data yang maksimal dan menunjukkan hasil yang baik, sehingga tulisan ini mencapai sasaran dan tujuan sesuai dengan judul yang telah ditetapkan, maka penulis mengumpulkan dan memperoleh data dengan menggunakan metode penelitian:

\subsection{Metode Pendekatan Masalah}

Metode adalah suatu cara yang teratur dan terpikir dengan baik-baik untuk mencapai tujuan tertentu, bahwa tujuan tertentu mengenai yang dilakukan harus mempunyai arah, sasaran atau maksud yang pasti, terang, nyata, atau jelas. ${ }^{8}$

Penelitian tentang Perlindungan Hukum bagi Konsumen dengan adanya Klausul Eksonerasi dalam Perjanjian Baku Sewa Guna Usaha (Leasing) dengan Perusahaan Pembiayaan PT. Dipo Star Finance cabang Padang (Studi Kasus Putusan Nomor 4/Pdt.G/2017/PN.Pdg) merupakan suatu penelitian hukum (yuridis normatif), yaitu yang artinya karya tulis ini mengacu pada normanorma hukum tertulis, baik yang dituangkan dalam bentuk peraturan maupun dalam bentuk literatur lainnya. ${ }^{9}$

\subsection{Jenis dan Sumber Data}

Penelitian ini menggunakan pendekatan bersifat persfektif analisis. Bersifat persfektif analisis maksudnya penelitian ini mempelajari tujuan hukum, nilai-nilai keadilan, validasi aturan hukum yang dihadapi. ${ }^{10}$ Analisis dimaksudkan berdasarkan gambaran fakta yang diperoleh akan dilakukan secara cermat bagaimana menjawab permasalahan. Jenis penelitian yang digunakan disesuaikan dengan permasalahan yang diangkat di dalamnya.

Jenis penelitian ini adalah penelitian hukum normatif. Penelitian hukum normatif yaitu penelitian yang dilakukan dengan cara menganalisa hukum yang tertulis dari bahan pustaka atau data sekunder belaka yang dikenal dengan nama bahan sekunder dan bahan acuan dalam bidang hukum atau bahan rujukan bidang hukum. Penelitian hukum

9 Soejono Soekanto, 1984, Pengantar Penelitian Hukum, Universitas Indonesia-Press Jakarta, hlm. 53

10 Peter Mahmud Marzuki, Penelitian Hukum, Kencana, Jakarta, 2010, hlm. 35. 
normatif dimaksudkan untuk mengadakan pendekatan terhadap masalah dengan cara melihat dari segi perundang-undangan yang berlaku serta doktrin-doktrin ahli hukum. Dalam penelitian ini, penelitian hukum normatif bertujuan untuk meneliti perlindungan hukum bagi konsumen dengan adanya klausul eksonerasi yang merugikan konsumen.

Pendekatan penelitian ini dilakukan dengan menggunakan pendekatan yuridis normatif atau pendekatan perundangundangan. Dengan tujuan untuk mengadakan pendekatan terhadap permasalahan dengan cara melihat dari segi peraturan perundang-undangan yang berlaku mengenai klausul eksonerasi yang merugikan konsumen berdasarkan putusan nomor 4/Pdt.G/2017/PN.Pdg), dengan tujuan untuk mempelajari penerapan norma-norma atau kaidah hukum yang dilakukan dalam praktek hukum.

Teknik pengumpulan data dilakukan melalui studi kepustakaan yaitu proses pengumpulan data dengan menggunakan bahan kepustakaan yang mempunyai hubungan dengan penulisan tesis ini tidak terbatas pada peraturan-peraturannya, tetapi juga buku-buku pendukung yang terkait dengan masalah perlindungan hukum bagi konsumen dan perjanjian baku pada umumnya dengan penulisan tesis ini.

Adapun jenis data yang dipergunakan oleh penulis terdiri dari:

1.) Bahan hukum primer, meliputi;

a. Undang-Undang Dasar 1945

b. Kitab Undang-Undang Hukum Perdata

c. Undang-Undang Nomor 8 Tahun 1999 tentang Perlindungan Konsumen

d. Peraturan Otoritas Jasa Keuangan Nomor 1 tahun 2013 tentang Perlindungan Konsumen Sektor Jasa Keuangan

e. Peraturan Presiden Nomor 9 Tahun 2009 tentang Lembaga Pembiayaan

f. Keputusan Menteri Keuangan Nomor 1169 Tahun 1991 tentang Kegiatan Sewa Guna Usaha

2.) Bahan hukum sekunder, meliputi buku-buku, makalah ilmiah dan bahan lain yang terkait dengan permasalahan yang akan dibahas.

3.) Bahan hukum tersier, yaitu bahan hukum yang memberikan petunjuk maupun penjelasan terhadap bahan 
hukum primer dan bahan hukum sekunder, seperti kamus, encyclopedia. ${ }^{11}$

\subsection{Teknik Pengumpulan Data}

Dalam pengumpulan data yang dilakukan dalam penelitian ini adalah Studi Dokumen, yaitu memperlajari dokumen-dokumen berupa data tertulis mengenai masalah yang diteliti seperti peraturan perundang-undangan yang berlaku, beserta ketentuan-ketentuan pelaksanaannya, dan putusan yang terkait dengan penelitian.

1.4. Teknik Pengolahan dan Analisis Data

Data yang telah diperoleh diolah dengan cara editing, yaitu data yang diperoleh tidak semuanya dimasukkan ke dalam hasil penelitian, namun dipilih terlebih dahulu data yang berkaitan dengan masalah yang diteliti, sehingga diperoleh data yang lebih terstruktur. Data tersebut diolah dan dianalisis secara data kualitatif yang bersifat yuridis, yaitu tidak menggunakan angka-angka (tidak menggunakan rumus matematika), tetapi menggunakan kalimat-kalimat yang merupakan pandangan para ahli, peraturan perundang-undangan, termasuk data yang penulis peroleh di

${ }^{11}$ Amiruddin dan H. Zainal Asikin, 2010, Pengantar Metode Penelitian Hukum, RajaGrafindo Persada, Jakarta, hlm. 32 lapangan yang memberikan gambaran secara rinci mengenai permasalahan.

\section{ANALISIS DAN PEMBAHASAN}

\subsection{Materi Muatan Klausul Eksonerasi}

Kitab Undang-Undang Hukum Perdata sesungguhnya menjelaskan tentang klausula eksonerasi yaitu pada Pasal 1493 yang menyatakan bahwa kedua belah pihak, dengan persetujuanpersetujuan istimewa boleh memperluas atau mengurangi kewajiban yang ditetapkan oleh undang-undang ini dan bahkan mereka boleh mengadakan persetujuan bahwa penjual tidak wajib menanggung sesuatu apapun. Dalam Pasal tersebut disebutkan kedua belah pihak, bukan salah satu pihak yang mana dalam prakteknya pengurangan atas kewajiban yang ditetapkan undangundang ini menjadi celah hukum bagi pelaku usaha dan dengan ditandatanganinya perjanjian baku itu maka pihak kedua dianggap setuju dengan pasal tersebut.

Pasal 9 ayat (1) Keputusan Menteri Keuangan No. 1169/KMK.01/1991 tentang Kegiatan Sewa Guna Usaha ditentukan bahwa setiap transaksi sewa guna usaha wajib diikat dalam suatu 
perjanjian sewa guna usaha (lease agreement). Mengenai isi dari kontrak sewa guna usaha, menurut Eddy P. Soekadi, suatu kontrak sewa guna usaha yang lengkap memuat hal-hal mengenai subjek perjanjian, objek perjanjian, jangka waktu, imbalan jasa sewa serta cara pembayarannya, hak opsi bagi leasse, kewajiban perpajakan, penutupan asuransi, tanggung jawab atas objek perjanjian, akibat kejadian lalai, serta akibat rusak atau hilangnya objek perjanjian sewa guna usaha. ${ }^{12}$

Pada umumnya, perusahaan pembiayaan menyodorkan kontrak baku kepada debitur atau penerima fasilitas atau konsumen. Debitur atau penerima fasilitas atau konsumen tinggal menyetujui atau tidak kontrak tersebut. Memang dalam realitasnya, perusahaan pembiayaan meminta kepada penerima fasilitas atau konsumen untuk membaca dan memahami isinya, namun ukuran font dalam kontrak tersebut kebanyakan menggunakan ukuran font kecil dengan kisaran 8 hingga 10 font size yang mana tulisannya akan sulit dibaca bagi sebagian orang. Apabila penerima fasilitas atau konsumen telah membaca dan dianggap memahami isinya, maka mereka diminta untuk menandatanganinya. Sementara itu isi kontrak ditentukan secara sepihak oleh perusahaan pembiayaan tanpa ada peluang bagi konsumen untuk merubah klausulnya. ${ }^{13}$

Pada umumnya, bunyi judul kontraknya adalah perjanjian pembiayaan konsumen, finance lease, operating lease, dan beberapa lainnya. Komparisinya meliputi kreditur atau pemberi fasilitas atau lessor dengan debitur atau penerima fasilitas atau lessee. Berikut ini disajikan substansi perjanjian sewa guna usaha finance lease yang dibuat antara PT Dipo Star Finance Cabang Padang sebagai kreditur atau lessor dengan Alexander sebagi debitur atau lessee. Ada 34 Pasal baku yang dimuat dalam perjanjian tersebut dengan objek pembiayaan barang modal berupa 1 unit Mitsubishi Pajero Sport GLS M/T 4X2 2011. Seluruh Pasal dalam perjanjian tersebut telah disiapkan oleh lessor secara sepihak dengan ukuran font yang cukup kecil dan hanya memuat 5 halaman saja. Lessee hanya diminta untuk mengisi data diri, objek barang modal yang diinginkan, jangka waktu yang ditawarkan lessor dan besaran Deposito Jaminan yang harus

13 Salim H.S, 2015, Hukum Kontrak, Perjanjian, Pinjaman dan Hibah, Sinar Grafika, Jakarta, hlm 54. 
dibayarkan tunai oleh lessee pada saat ditandatanganinya perjanjian tersebut.

Setelah perjanjian lease dibuat pada tanggal 06 Oktober 2011 antara PT Dipo Star Finance Cabang Padang sebagai lessor dengan Alexander sebagi lessee berjalan, beberapa bulan kemudian, tepatnya tanggal 08 Desember 2011 antara PT Dipo Star Finance Cabang Padang dengan Alexander membuat perjanjian lease/finance lease baru dan terpisah dengan perjanjian sebelumnya dengan objek 1 unit Mitsubishi Fuso Truck E2 FN527ML 2011/ 1 unit Karoseri Dump Truck 2011. Pada perjanjian lease kedua tersebut isi dari perjanjian pertama sama persis dengan isi perjanjian kedua, yang membedakannya hanya objek barang pembiayaan, besaran Deposito Jaminan, dan jangka waktu yang ditawarkan lessor. Dalam hal ini lessor tidak menjelaskan mengenai Ketentuan Keterkaitan terhadap perjanjian pertama dengan perjanjian kedua.

Pada tanggal 10 November 2014 Alexander sebagai lessee telah melunasi seluruh angsuran termasuk denda keterlambatannya pada perjanjian finance lease pertama yang dibuat pada tanggal 06 Oktober 2011 lalu terhadap objek perjanjian lease berupa 1 unit Mitsubishi Pajero Sport GLS. Karena angsuran telah lunas maka lessee/konsumen meminta penyerahan Buku Pemilik Kendaraan Bermotor (BPKB) mobil tersebut, akan tetapi debitur atau lessor tidak bersedia memberikannya kepada lessee dengan alasan lessee masih mempunyai hutang kredit lainnya yaitu perjanjian finance lease kedua yang dibuat pada tanggal 08 Desember 2011.

Terjadinya jual beli antara lessee dan lessor berdasarkan hak opsi membeli maka terhadap hak kepemilikan objek tersebut demi hukum beralih kepada lessee, namun lessor tetap menangguhkan penyerahan $\mathrm{BPKB}$ tersebut dengan alasan lessor masih terikat perjanjian baku pada pasal 29 yang berbunyi:

1. Dalam hal lessee disamping memperoleh fasilitas leasing berdasarkan Perjanjian ini, juga memperoleh fasilitas pembiayaan dari Lessor, baik dalam bentuk fasilitas leasing atau fasilitas pembiayaan lainnya, maka kelalaian atas salah satu perjanjian pembiayaan itu akan merupakan kelalaian atas Perjanjian ini, juga kelalaian atas Perjanjian ini akan merupakan kelalaian atas perjanjian atau perjanjian-perjanjian pembiayaan lainnya itu.

2. Pada Kelalaian menurut ayat lalu, maka hak-hak yang dimiliki oleh Lessee dalam Perjanjian ini akan merupakan jaminan terhadap kewajiban-kewajibannya dalam perjanjian pembiayaan yang lainnya itu dan sebaliknya hak-hak dalam perjanjian pembiayaan lainnya dengan sendirinya menjadi jaminan terhadap kewajiban Lease menurut Perjanjian ini. 
Ketentuan keterkaian yang diatur di dalam Pasal 29 perjanjian finance lease merupakan klausul baku yang memuat ketentuan eksonerasi yang membebaskan lessor dari kewajibannya untuk menyerahkan BPKP objek perjanjian lease tersebut, hal ini termuat pada kalimat "hak-hak yang dimiliki oleh Lessee dalam Perjanjian ini akan merupakan jaminan terhadap kewajibankewajibannya dalam perjanjian pembiayaan yang lainnya itu dan sebaliknya hak-hak dalam perjanjian pembiayaan lainnya dengan sendirinya menjadi jaminan terhadap kewajiban Lease menurut Perjanjian ini." sehingga hal ini telah merugikan pihak lessee, baik secara materil maupun inmateril.

\subsection{Kerugian Bagi Konsumen}

Dengan telah dibayarkannya seluruh angsuran kredit, denda keterlambatnya dan jangka waktu yang telah ditentukan dalam perjanjian lease pertama terhadap objek tersebut maka, seharusnya perjanjian pertama telah berakhir, karena mengingat sebab berakhirnya suatu perjanjian atau hapusnya perjanjian sebagaimana yang tercantum pada pasal 1380 KUHPerdata adalah dengan pembayaran dan berakhirnya jangka waktu yang telah disepakati. Dalam perjanjian finance lease tersebut adanya hak opsi bagi lessee untuk membeli objek yang disewa guna usahakan dimana hal itu telah dimuat di dalam Pasal 4 perjanjian tersebut. Dalam hal ini keinginan lessee untuk membeli objek direalisasikan dengan cara penyerahan uang Deposito Jaminan pada saat penandatanganan perjanjian yang mana setelah berakhirnya jangka waktu lease, lessee memilih opsi untuk membeli objek, maka Uang Deposito Jaminan tersebut akan dikompensasikan dengan nilai sisa barang. Sehingga dapat dikatakan bahwa uang Deposito Jaminan digunakan untuk membeli nilai sisa barang kepada lessor, maka dalam hal ini terjadilah jual beli antara lessee dengan lessor berdasarkan hak opsi membeli yang disebutkan dalam pasal 4 perjanjian tersebut.

Pada waktu lahirnya perjanjian terdapat cacat kehendak mengenai Pasal 29 dalam perjanjian lease tersebut. Lessee meyakini dan menghendaki bahwa jaminan terhadap perjanjian finance lease adalah objek dari masing-masing perjanjian itu sendiri yang mana dalam keadaan belum lunas pembayarannya dan lessee sadar bahwa objek yang belum lunas angsurannya bukan sepenuhnya milik lessee karena dalam hal ini lessee masih berstatus sebagai penyewa. Akan tetapi lessee tidak mengetahui bahwa jaminan terhadap perjanjian yang telah berakhir merupakan jaminan terhadap perjanjian 
lain yang masih berjalan, dalam hal ini lessee sebagai pemilik objek karena telah menggunakan hak opsinya untuk membeli nilai sisa barang.

Jika dilihat lebih teliti lagi pada poinpoin Pasal 29 Perjanjian finane lease tidak ditemukan pernyataan atau kata yang menegaskan mengenai objek jaminan terhadap perjanjian ini atau perjanjian lain adalah termasuk perjanjian lain atau perjanjian ini walaupun telah lunas atau berakhir, sehingga jaminan dalam Pasal 29 menjadi multitafsir yang mana jaminan tersebut apakah terhadap objek yang masih berjalan waktunya atau termasuk objek yang telah lunas pembayarannya.

Secara yuridis perbuatan yang mencantumkan klausul eksonerasi di dalam suatu perjanjian merupakan perbuatan yang dilarang, namun pencantuman itu sering kali terjadi dalam praktik perjanjian. Sebagian pelaku usaha cenderung mencantumkan klausul eksonerasi dalam format (formulir) perjanjian baku. Perjanjian baku merupakan perjanjian yang mengikat para pihak yang menandatanganinya, walaupun harus diakui bahwa klausul yang terdapat dalam perjanjian baku banyak mengalihkan beban tanggung

${ }^{14}$ Ahmadi Miru dan Sutarman Yodo, Op., Cit, hlm 118. jawab dari pihak perancang klausul baku kepada pihak lawannya. Namun setiap kerugian yang timbul di kemudian hari akan tetap ditanggung oleh para pihak yang harus bertanggung jawab berdasarkan klausula perjanjian tersebut, kecuali jika klausula tersebut merupakan klausula yang jelas dilarang berdasarkan Pasal 18 UUPK. ${ }^{14}$

\subsection{Pertimbangan Hakim}

Pengadilan berfungsi menyelenggarakan peradilan guna menegakkan hukum dan keadilan berdasarkan Pancasila dan UndangUndang Dasar Tahun 1945 demi terselenggaranya negara hukum. Hakim merupakan pelaku utama fungsi pengadilan, karena itu semua wewenang dan tugas yang dimiliki oleh hakim harus dilaksanakan dalam rangka menegakkan hukum dan keadilan. $^{15}$ Hakim dalam memberi suatu keadilan harus menelaah terlebih dahulu tentang kebenaran peristiwa yang diajukan kepadanya kemudian memberi penilaian terhadap peristiwa tersebut dan menghubungkannya dengan hukum yang berlaku. Setelah itu hakim baru dapat menjatuhkan putusan tesebut.

${ }^{15}$ Syarif Mappiasse, 2015, Logika Hukum Pertimbangan Putusan Hakim, Kencana, Jakarta, hlm. 91. 
Pembedaan kualifikasi gugatan lebih banyak digantungkan pada situasi konkret yang diungkapkan dalam fakta-fakta hukum (posita gugatan) serta diberikan pertimbangan hukum oleh hakim. Artinya, tidak hanya 1 (satu) kualifikasi gugatan saja yang disebutkan dalam gugatan. Menurut Az Nasution, penyebutan 3 (tiga) kualifikasi gugatan sekaligus (wanprestasi, perbuatan melawan hukum, dan perbuatan melawan hukum penguasa) sama sekali tidak dimungkinkan. Apabila diruntut sejarah dan sistematis perundang-undangan, meskipun wanprestasi tidak termasuk dalam perbuatan melawan hukum, tidak menghalangi penggugat untuk menggugat berdasarkan perbuatan melawan hukum. ${ }^{16}$

Terhadap perkara perjanjian baku sewa guna usaha (finance lease) yang merugikan pihak konsumen ini antara Alexander sebagi lessee dengan PT Dipo Star Finance Cabang Padang sebagai lessor, telah ditetapkan putusannya dengan Pertimbangan Hakim dalam memutuskan Pokok Perkara Perjanjian Baku Sewa Guna Usaha (Leasing) Berdasarkan Putusan Nomor 4/PDT.G/2017/PN.PDG, bahwa:

16 Achmad Ali, 2009, Menguak Teori Hukum (Legal Theory) dan Teori Peradilan (Judicialprudence), Kencana, Jakarta, hlm. 292.
Berdasarkan bantahan dari lessor sebagai tergugat yaitu gugatan lessee sebagai penggugat kabur dan tidak jelas (Obscuur Libelli), dengan alasan bahwa penggugat di dalam gugatannya telah menggabungkan dalil gugatan antara Gugatan Perbuatan Melawan Hukum dengan Gugatan Ingkar Janji. Dasar hukum dari PMH tidak diuraikan oleh penggugat dalam gugatannya. Penggugat tidak menyebutkan mengenai aturan undang-undang yang mana yang telah dilanggar oleh tergugat. Oleh karena itu gugatan penggugat tidak dapat diterima (niet on vankelijke verklaard).

Penggugat dalam dalil gugatannya menyatakan, tindakan dari tergugat I yang menahan BPKB Mitsubishi Pajero Sport GLS M/T 4x2 Nomor Mesin 4D56UCC755 No.Pol BA 80 YY milik PENGGUGAT sebagai Perbuatan Melawan Hukum, padahal penggugat sendiri telah melakukan Perbuatan Ingkar Janji (Wanprestasi). Dengan demikian gugatan dari PENGGUGAT haruslah digugurkan atau dinyatakan tidak diterima.

Dalil Penggugat yang disampaikan dalam posita gugatan pada pokoknya menyatakan bahwa antara Penggugat dan 
Tergugat I telah terjadi hubungan hukum dengan perjanjian nomor pinjam meminjam uang dengan 0008162/09/10/2011 pada tanggal 6 berdasarkan perjanjian kredit untuk pembelian 1 (satu) unit mobil dengan jaminan BPKB. Penggugat telah melakukan pelunasan kepada Tergugat I dan oleh karenanya menurut Penggugat, Tergugat I berkewajiban menyerahkan jaminan BPKB tersebut kepada Penggugat. Atas tindakan yang dilakukan oleh Tergugat I tersebut, Penggugat dalam petitumnya point lainnya menyatakan agar Tergugat I dinyatakan telah melakukan perbuatan melawan hukum.

Maksud dan tujuan gugatan Penggugat yang pada pokoknya adalah mengenai perbuatan melawan hukum Tergugat yang tidak memberikan Buku pemilik Kendaraan Bermotor (BPKB) mobil Mitsubishi Pajero Sport GLS M/T 4×2 NOMOR MESIN 4D56UCC6755 nomor polisi BA 80 YY WARNA ABUABU TUA milik penggugat dengan alasan penggugat mempunyai hutang kredit lainnya. Tergugat I telah membantahnya dengan dalil bahwa benar antara Penggugat dan Tergugat I telah mengadakan perjanjian pembelian 1 (satu) unit mobil Mitsubishi Pajero Sport GLS M/T 4x2 Nomor Mesin 4D56UCC6755 nomor polisi BA $80 \mathrm{YY}$ Warna Abu-Abu Tua secara kredit Oktober 2011 serta telah melunasinya. Akan tetapi antara Penggugat dengan Tergugat I juga telah mengadakan perjanjian lainnya yaitu perjanjian nomor 0008592/1/09/12/2011 atas satu unit Fuso Truck E-2 Tahun 2011 tertanggal 08 Desember 2011. Bahwa kedua perjanjian ini adalah saling berkaitan satu sama lain. Artinya walaupun Penggugat telah melunasi perjanjian nomor 0008162/09/10/2011 pada tanggal 6 Oktober, namun Penggugat belum menyelesaikan ataupun melunasi Perjanjian lainnya yaitu perjanjian nomor 0008592/1/09/12/2011 atas satu unit Fuso Truck E-2 Tahun 2011 tertanggal 09 Desember 2011. Bahwa dengan tidak dipenuhinya salah satu dari Perjanjian fasilitas pembiayaan oleh Penggugat maka secara hukum Tergugat I dapat menolak untuk memberikan BPKB Mitsubishi Pajero Sport GLS M/T 4x2 Nomor Mesin 4D56UCC6755 nomor polisi BA 80 YY milik Penggugat.

BPKB mobil Pajero Sport 2,5 D GLS BA 80 YY telah dijaminkan Penggugat kepada Tergugat I atas dasar Perjanjian nomor 0008162/09/10/2011 pada tanggal 6 Oktober 2011 sebagaimana bukti T-3, Penggugat dengan Tergugat I juga telah mengadakan perjanjian lainnya 
yaitu perjanjian nomor 0008592/1/09/12/2011 atas satu unit

Fuso Truck E-2 Tahun 2011 tertanggal 08

Desember 2011 sebagai bukti T-2. Berdasarkan bukti T-6, T-7 dan T-8 Tergugat I telah memberikan peringatan atas kelalaian Penggugat atas cicilan pembayaran perjanjian nomor 0008592/1/09/12/2011:

Tergugat I telah menghadirkan ahli hukum perjanjian yaitu Dr. Busyra Azheri, S.H, MH (lk), yang pada pokoknya memberikan pendapat, bahwa :

Ketentuan Keterkaitan sebagaimana diatur pada pasal 29 perjanjian leasing (sewa guna usaha) yang disiapkan oleh pihak PT. Dipo Star Finance bukti T-2, menegaskan sebagai berikut:

1. Dalam hal lessee disamping memperoleh fasilitas leasing berdasarkan perjanjian ini juga memperoleh fasilitas pembiayaan dari Lassoer baik dalam bentuk fasilitas leasing atau fasilitas pembiayaan lainnya. Jika kelalaian atas salah satu perjanjian pembiayaan itu akan merupakan kelalaian ini akan merupakan kelalaian atas perjanjian atau perjanjian-perjanjian pembiayaan lainnya.

2. Pada kelalaian menurut ayat lalu, maka hak yang dimiliki oleh lessee dalam perjanjian ini akan merupakan jaminan terhadap kewajibankewajibannya dalam perjanjian pembiayaan lainnya dengan sendirinya menjadi jaminan terhadap kewajiban lease menurut perjanjian ini;
Pada akhir putusan Majelis Hakim mengadili dalam gugatan awal dan dalam bantahan tergugat dengan menolak bantahan tergugat. Mengadili dalam pokok perkara dengan menolak gugatan Penggugat seluruhnya.

Mengenai pertimbangan majelis hakim dalam memutuskan pokok perkara finance lease tersebut belum mencerminkan perlindungan hukum dari segi perlindungan refresif, karena dalam berbagai pertimbangan tersebut hakim sendiri belum memahami apa yang sebenarnya terjadi dalam pokok perkara di atas, hakim berpedoman kepada bantahan-bantahan yang diajukan oleh para tergugat tanpa menyadari bahwa perjanjian yang dibuat oleh para pihak merupakan perjanjian baku yang memuat klausul eksonerasi.

Terhadap perjanjian tersebut hakim juga mengartikan kesepakatan yang terjadi antara para pihak merupakan perjanjian pinjam meminjam uang dengan jaminan $\mathrm{BPKB}$ mobil dan perjanjian kredit pembelian 1 unit mobil, padahal jika hakim melihat lebih teliti dari judul perjanjian itu sendiri telah jelas bahwa hubungan hukum yang terjadi antara para pihak merupakan hubungan hukum perjanjian sewa guna usaha dengan hak opsi (finance lease) yang kemudian di dalam pasal-pasalnya sendiri 
menyebutkan bahwa ada hak opsi untuk membeli bagi lessee.

Mengenai pertimbangan hakim dalam dalil dari gugatan penggugat yang menggabungkan antara perbuatan melawan hukum dengan wanprestasi dalam satu gugatan merupakan kabut atau tidak jelas, jika dibaca kembali mengenai pokok perkara dalam putusan tersebut, penggugat tidak menyebutkan bahwa tergugat wanprestasi tapi penggugat dengan jelas menggugat si tergugat dengan dalil PMH karena penggugat telah mengalami kerugian secara materi maupun inmateri terhadap klausul eksonerasi pada Pasal 29 perjanjian lease tersebut. Dalam aspek hukum perdata Perbuatan Melawan Hukum diatur di dalam Pasal 1365 KUH Perdata yang berbunyi "Tiap perbuatan yang melanggar hukum, yang membawa kerugian kepada orang lain, mewajibkan orang yang karena salahnya menerbitkan kerugian itu, mengganti kerugian tersebut".

Tindakan dari tergugat menahan BPKB objek perjanjian yang berakhir dengan opsi pembelian merupakan hal yang salah karena perjanjian antara penggugat dengan tergugat adalah perjanjian sewa guna usaha yang tujuannya adalah pembiayaan barang modal untuk digunakan oleh penggugat dalam suatu usaha dengan jangka waktu tertentu berdasarkan pembayaran secara berkala disertai dengan hak opsi untuk membeli barang yang bersangkutan berdasarkan nilai sisa yang telah disepakati bersama. Pada dasarnya selama jangka waktu tertentu yang telah disepakati bersama tersebut objek merupakan milik tergugat karena penggugat hanya penyewa untuk menjalankan usahanya, namun setelah jangka waktu berakhir dan penggugat menggunakan hak opsinya untuk membeli dengan cara mengkompensasikan deposito jaminan yang telah diberikan diawal lahirnya perjanjian, maka saat itu terjadi perbuatan hukum jual beli antara penggugat dengan tergugat, maka penggugat adalah pemilik dari objek tersebut.

Mengenai jaminan, pada dasarnya barang modal yang digunakan dalam menjalankan usaha oleh penggugat merupakan milik tergugat selama jangka waktu yang ditentukan karena penggugat hanyalah penyewa, dalam hal ini jika barang milik sendiri yang disewa oleh orang lain menjadi jaminan apakah hal itu merupakan hal yang lazim atau tidak, tanpa menjaminkanpun pemilik tetap punya hak absulete terhadap benda tersebut karena pada dasarnya ia adalah pemilik dan orang lain hanya penyewa, 
sehingga hal ini yang membedakan antara leasing dengan sewa beli maupun jual beli secara angsuran.

\section{KESIMPULAN}

Kegiatan sewa guna usaha mengharuskan setiap transaksi sewa guna usaha wajib diikat dalam suatu perjanjian sewa guna usaha/lease agreement berdasarkan Pasal 9 ayat (1) Keputusan Menteri Keuangan No. 1169/KMK.01/1991 tentang Kegiatan Sewa Guna Usaha. Karena undangundang hanya menyebutkan perjanjian dalam bentuk tertulis, maka pelaku usaha cenderung menggunakan kontrak baku. Mengenai Pasal 29 dalam perjanjian lease tersebut. Lessee meyakini dan menghendaki bahwa jaminan terhadap perjanjian finance lease adalah objek dari masing-masing perjanjian itu sendiri yang mana dalam keadaan belum lunas pembayarannya dan lessee sadar bahwa objek yang belum lunas angsurannya bukan sepenuhnya milik lessee karena dalam hal ini lessee masih berstatus sebagai penyewa. Akan tetapi lessee tidak mengetahui bahwa jaminan terhadap perjanjian yang telah berakhir merupakan jaminan terhadap perjanjian lain yang masih berjalan, dalam hal ini lessee sebagai pemilik objek karena telah menggunakan hak opsinya untuk membeli nilai sisa barang. Pada poin-poin Pasal 29
Perjanjian finane lease tidak ditemukan pernyataan atau kata yang menegaskan mengenai objek jaminan terhadap perjanjian ini atau perjanjian lain adalah termasuk jaminan perjanjian lain atau perjanjian ini walaupun telah lunas atau berakhir, sehingga jaminan dalam Pasal 29 menjadi multitafsir yang mana jaminan tersebut apakah terhadap objek yang masih berjalan waktunya atau termasuk objek yang telah lunas pembayarannya.

Pertimbangan hakim dalam dalil dari gugatan penggugat yang menggabungkan antara perbuatan melawan hukum dengan wanprestasi dalam satu gugatan merupakan kabur atau tidak jelas, jika dibaca kembali mengenai pokok perkara dalam putusan tersebut, penggugat tidak menyebutkan bahwa tergugat wanprestasi tapi penggugat dengan jelas menggugat si tergugat dengan dalil PMH karena penggugat telah mengalami kerugian secara materi maupun inmateri terhadap klausul eksonerasi pada Pasal 29 perjanjian lease tersebut. Dalam aspek hukum perdata Perbuatan Melawan Hukum diatur di dalam Pasal 1365 KUHPerdata yang berbunyi "Tiap perbuatan yang melanggar hukum, yang membawa kerugian kepada orang lain, mewajibkan orang yang karena salahnya menerbitkan kerugian itu, mengganti kerugian tersebut". 


\section{DAFTAR KEPUSTAKAAN}

Abdulkadir Muhammad dan Rilda Murniati, 2000, Segi Hukum Lembaga Kenangan dan Pembiayaan. PT. Citra Aditya Bakti, Bandung.

Achmad Ali, 2009, Menguak Teori Hukum (Legal Theory) dan Teori Peradilan (Judicialprudence), Kencana, Jakarta.

Ahmadi Miru dan Sutarman Yodo, 2008, Hukum Perlindungan Konsumen, PT RajaGrafindo Persada, Jakarta.

Amiruddin dan H. Zainal Asikin, 2010, Pengantar Metode Penelitian Hukum, RajaGrafindo Persada, Jakarta.

Herlien Budiono, 2010, Ajaran Umum Hukum Perjanjian dan Penerapannya di Bidang Kenotariatan, Citra Aditya, Bandung.

Keputusan Menteri Keuangan Nomor 1169 Tahun 1991 tentang Kegiatan Sewa Guna Usaha.

Kitab Undang-Undang Hukum Perdata

Mariam Darus Badrulzaman, 2008, Aneka Hukum Bisnis, Alumni, Bandung.

Maxmanroe.com, Pengertian Modal Secara Umum, Manfaat, Sumber, dan Jenis-Jenis Modal, https://www.maxmanroe.com/vid/bisnis/pengertian-modal.html, Terakhir diakses tanggal 2 Desember 2018.

Munir Fuady, 2003, Hukum Kontrak (Dari Sudut Pandang Hukum Bisnis), Buku Kedua, Citra Aditya Bakti, Bandung.

Peraturan Presiden Nomor 9 Tahun 2009 tentang Lembaga Pembiayaan

Peter Mahmud Marzuki, 2010, Penelitian Hukum, Kencana, Jakarta.

Ronny Hanitijo Soemitro, 2001, Metode Penelitian Hukum dan Jurimetri, Ghalia Indonesia, Jakarta.

Salim H.S, 2015, Hukum Kontrak, Perjanjian, Pinjaman dan Hibah, Sinar Grafika, Jakarta.

Soerjono Soekanto, 1984, Pengantar Penelitian Hukum, UI Press, Jakarta.

Sunaryo, 2009, Hukum Lembaga Pembiayaan, Sinar Grafika, Jakarta.

Syarif Mappiasse, 2015, Logika Hukum Pertimbangan Putusan Hakim, Kencana, Jakarta.

Undang-Undang Dasar Tahun 1945

Undang-Undang Nomor 8 Tahun 1999 tentang Perlindungan Konsumen 
ALHURRIYAH : Jurnal Hukum

Islam
eISSN: 2549-4198

pISSN: 2549-3809
Vol. 05. No. 01. Januari-Juni 2020 